\title{
Adaptabilitas Genotipe Gandum Introduksi di Dataran Rendah
}

\author{
Adaptability of Introduced Wheat Genotypes at Low Altitude \\ Yudiwanti Wahyu $^{1 *}$, Aditya Permana Samosir ${ }^{1}$, Sri Gajatri Budiarti ${ }^{2}$ \\ ${ }^{1}$ Departemen Agronomi dan Hortikultura, Fakultas Pertanian, Institut Pertanian Bogor \\ (Bogor Agricultural University), Jl. Meranti, Kampus IPB Darmaga, Bogor 16680, Indonesia \\ Telp.\&Faks.62-251-8629353 e-mail agronipb@indo.net.id \\ ${ }^{2}$ Balai Besar Libang Bioteknologi dan Sumberdaya Genetik Pertanian (BB BIOGEN), \\ Jl. Tentara Pelajar 3A, Bogor 16111, Indonesia
}

\begin{abstract}
The experiment was conducted to study the adaptability of ten introduced wheat genotypes in Bogor, held at SEAMEO BIOTROP Experimental Field, Tajur, Bogor in March-July 2011. Experiments using Randomized Completely Block Design, single factor and three replications. The factor was genotype consisting of wheat genotypes introduced from India (OASIS / SKAUZ / / 4 * BCN-Var 28, HP 1744, LAJ/MO88, RABE/MO88), Turkey (Basribey, Alibey and Menemen), CIMMYT (G-21, G-18 and H-21), as well as two national varieties (Dewata and Selayar) as a control. The results showed that the varieties significantly affect the overall character except number of tillers and number of productive tillers. Menemen is introduced genotype that showed better or no different performance for almost all the characters than Dewata and Selayar as controls.
\end{abstract}

Key words: Dewata, low altitute, Menemen, Selayar

\section{ABSTRAK}

Percobaan ini dilakukan untuk mempelajari adaptabilitas sepuluh genotipe gandum introduksi di Bogor yang dilaksanakan di Kebun Percobaan SEAMEO BIOTROP, Tajur, Bogor pada bulan Maret-Juli 2011. Percobaan menggunakan Rancangan Kelompok Lengkap Teracak, satu faktor dan tiga ulangan. Faktor tersebut adalah genotipe yang terdiri atas genotipe gandum introduksi dari India (OASIS/SKAUZ//4*BCN-Var 28, HP 1744, LAJ/MO88, RABE/MO88), Turki (Basribey, Alibey dan Menemen), CIMMYT (G-21, G-18 dan H-21), serta dua varietas unggul nasional (Dewata dan Selayar) sebagai pembanding. Hasil penelitian menunjukkan bahwa varietas berpengaruh nyata terhadap keseluruhan karakter kecuali karakter jumlah anakan dan jumlah anakan produktif. Menemen adalah genotipe introduksi yang menunjukkan keragaan lebih baik atau tidak berbeda untuk hampir semua karakter dibanding Selayar atau Dewata sebagai pembanding.

Kata kunci: dataran rendah, Dewata, Menemen, Selayar

\section{PENDAHULUAN}

Gandum (Triticum aestivum L.) merupakan pangan pokok bagi sebagian besar penduduk dunia. Keragaman nutrisi yang tinggi menjadikan gandum sebagai bahan makanan pokok lebih dari sepertiga populasi dunia (Porter, 2005). Gandum mempunyai prospek yang sangat besar mengingat luasnya potensi lahan yang dapat ditanami oleh tanaman yang

\footnotetext{
* Penulis untuk korespondensi. e-mail: yudiwanti@ipb.ac.id
}

mempunyai kandungan karbohidrat sebesar $70 \%$ dan protein sebesar $13 \%$ ini. Tanaman serealia non beras ini juga telah diidentifikasi sangat cocok untuk agroklimat di Indonesia (Wibowo, 2009).

Tanaman yang juga berperan sebagai tanaman industri makanan olahan ini mempunyai peran strategis dalam memenuhi kebutuhan tepung terigu masyarakat Indonesia. Saat ini, ketergantungan Indonesia terhadap impor gandum sangat tinggi. Data dari Aptindo menunjukkan bahwa pada tahun 2010, impor gandum Indonesia mencapai 4.5 juta ton. 
Wibowo (2009) menyatakan bahwa hal ini disebabkan karena pengembangan budidaya gandum di Indonesia masih sangat terbatas. Selain itu juga, karena masih kentalnya pendapat yang menyebutkan bahwa gandum tidak dapat ditanam di Indonesia karena tanaman tersebut adalah tanaman sub tropis. Hasil penelitian membuktikan bahwa tanaman gandum dapat tumbuh dan berproduksi dengan baik di Indonesia serta mempunyai peluang untuk pengembangannya. Dahlan et al. (2003) menyatakan bahwa hasil gandum di Lembang, Jawa Barat (1100 m dpl) mencapai 3.34 ton $\mathrm{ha}^{-1}$, varietas Nias di Malino dapat menghasilkan 5.37 ton ha ${ }^{-1}$ pada 2001 dan gandum yang ditanam di daerah Cangar, Jawa Timur (1700 m dpl) pada musim kemarau tahun 2000 mampu memproduksi hasil biji sebesar 3.5 - 4.0 ton $\mathrm{ha}^{-1}$.

Farid (2006) menyatakan bahwa terbatasnya luas dataran tinggi yang banyak ditanami dengan komoditas hortikultura yang mempunyai nilai ekonomis tinggi juga berpengaruh terhadap pengembangan gandum di Indonesia sehingga diperlukan pengembangan gandum yang toleran dataran rendah $(<400 \mathrm{~m} \mathrm{dpl})$. Kendala utama yang dihadapi dalam pengembangan gandum ini adalah cekaman lingkungan di dataran rendah khususnya cekaman suhu tinggi.

Bererapapenelitian dalam rangka pengembangan gandum yang toleran dataran rendah sudah dilakukan di Indonesia. Balitsereal (2009) melaporkan hasil pertanaman gandum pada percobaan yang dilakukan di Merauke, Papua (15 m dpl) dapat mencapai 2.37 ton/ha.

Saat ini, varietas gandum yang telah dirilis adalah varietas Selayar dan Dewata yang merupakan gandum adaptif dataran tinggi (Dahlan et al., 2003). Siagian (2008) menyatakan bahwa pemerintah sedang melakukan uji coba untuk varietas gandum yang sesuai di dataran rendah. Dengan demikian, penelitian yang bertujuan untuk mempelajari daya hasil sepuluh genotipe gandum introduksi di Bogor ini sesuai dengan arah pengembangan varietas gandum di Indonesia.

Penelitian ini bertujuan untuk mempelajari daya hasil sepuluh genotipe gandum introduksi di dataran rendah dengan Bogor sebagai lokasi contoh.

\section{BAHAN DAN METODE}

PercobaaninidilaksanakandiKebunPercobaan Southeast Asian Regional Centre for Tropical Biology (SEAMEO BIOTROP), Tajur, Bogor yang mempunyai ketinggian \pm 300 meter di atas permukaan air laut mulai bulan Maret hingga Juli 2011.

Bahan yang akan digunakan adalah 10 genotipe gandum introduksi dari India (OASIS/SKAUZ//
4*BCN-Var 28, HP 1744, LAJ/MO88, RABE/MO88), Turki (Basribey, Alibey dan Menemen), CIMMYT (G-21, G-18 dan H-21), dua varietas unggul nasional sebagai pembanding (Dewata dan Selayar), bokashi, pupuk urea, SP-36, KCL, Score 250 EC yang berfungsi sebagai fungisida sistemik, Sevin, Meothrin 50 EC yang berperan sebagai insektisida dan akarisida racun kontak dan lambung, bambu, plastik serta jaringjaring.

Percobaan dilakukan dengan menggunakan Rancangan Kelompok Lengkap Teracak (RKLT) faktor tunggal dengan 12 genotipe gandum sebagai perlakuan yang diulang sebanyak 3 kali sehingga secara keseluruhan terdapat 36 satuan percobaan. Satuan percobaan berupa petakan berukuran $1.5 \times 5$ $\mathrm{m}^{2}$.

Pengolahan tanah dilakukan satu minggu sebelum penanaman. Penanaman dilakukan dengan jarak tanam $25 \mathrm{~cm}$ antar baris dan benih dilarik dalam baris sepanjang $5 \mathrm{~m}$. Pada tiap baris ditanam 11-12 g benih sehingga dalam tiap petak benih yang digunakan adalah $66 \mathrm{~g}$ untuk 6 baris tanaman. Pemupukan dilakukan dengan cara dialur antar barisan tanaman (5-7 cm). Pupuk pertama diberikan saat 10 hari setelah tanam (HST) dengan dosis $50 \% \mathrm{~N} / \mathrm{ha}, 100 \% \mathrm{P}_{2} \mathrm{O}_{5} / \mathrm{ha}$, dan $100 \% \mathrm{~K}_{2} \mathrm{O} / \mathrm{ha}$. Pemupukan kedua diberikan saat 30 HST dengan dosis $50 \% \mathrm{~N} / \mathrm{ha}$. Pengendalian gulma dilakukan tiap minggu. Hama dan penyakit tanaman dikendalikan sesuai dengan tingkat serangan.

Panen dilakukan secara bertahap tergantung pada tingkat kematangan tiap genotipe. Hasil panen per petakan dibedakan menjadi tiga bagian, yaitu hasil luar, hasil tengah, dan hasil pinggir. Hasil luar merupakan hasil panen yang diperoleh dari baris terluar tiap petakan (baris 1 dan 6). Hasil tengah diperoleh dari 2 baris tengah sepanjang $4.5 \mathrm{~m}$, sedangkan hasil pinggir diperoleh dari baris 2 dan 5 serta $0.25 \mathrm{~m}$ pada kedua ujung 2 baris tengah, kemudian masing-masing hasil panen ditimbang.

Peubah diamati pada 10 tanaman contoh secara acak pada tiap petak, kecuali untuk pengamatan umur berbunga, umur panen, jumlah malai ubinan, bobot 1,000 butir dan hasil panen per petak. Peubah tersebut adalah: (1) umur berbunga (hari), diamati pada waktu malai telah keluar dan mekar dari $50 \%$ populasi yang diamati. Mekarnya bunga (floret) ditandai oleh terlihatnya kantong sari (anther) yang menjuntai keluar dari bunga. (2) Umur panen (hari), saat 75\% tanaman dalam populasi telah siap panen ditandai oleh mengeringnya daun dan batang tanaman dan malai berisi penuh biji. (3) Tinggi tanaman (cm), diukur dari pangkal batang hingga ujung malai (spikes), tidak termasuk bulu malai (awnless) dan dilakukan 
menjelang panen. (4) Panjang malai (cm), diukur dari cabang malai paling bawah (pangkal) sampai ujung malai, tidak termasuk bulu malai (awnless) dan dilakukan menjelang panen. (5) Jumlah malai ubinan, dihitung dari bagian tengah barisan tanaman dengan ukuran $1 \mathrm{~m}^{2}$ dan dilakukan saat panen. (6) Jumlah biji per malai, diambil dari 10 malai contoh dan dihitung pada saat perontokan biji. (7) Jumlah anakan, dihitung pada saat panen. (8) Jumlah anakan produktif, dihitung berdasarkan anakan yang menghasilkan malai pada saat panen. (9) Jumlah spikelet per malai, dihitung pada saat panen. (10) Jumlah floret hampa per malai, dihitung pada saat panen. (11) Bobot biji per malai (g), dilakukan setelah biji dikeringkan kemudian ditimbang. (12) Bobot 1000 butir (g) adalah bobot 1000 biji yang diambil secara acak pada kadar air biji 14\%. (12) Hasil panen per petak (g) adalah bobot seluruh biji dari tanaman di 2 baris tengah sepanjang $4.5 \mathrm{~m}$ tidak termasuk tanaman pada $0.25 \mathrm{~m}$ di kedua ujung tiap baris.

Terhadap data yang diperoleh dilakukan analisis ragam. Untuk karakter yang pengaruh genotipenya nyata dilakukan uji nilai tengah tiap genotipe gandum introduksi dengan varietas Dewata atau Selayar sebagai pembanding menggunakan uji t-Dunnett.

\section{HASIL DAN PEMBAHASAN}

\section{Pertumbuhan Vegetatif dan Generatif}

Pertumbuhan vegetatif dan generatif mencakup karakter tinggi tanaman, jumlah anakan, umur berbunga, jumlah anakan produktif dan umur panen. Genotipe berpengaruh sangat nyata terhadap tinggi tanaman, umur berbunga, dan umur panena, tetapi tidak berpengaruh terhadap jumlah anakan dan jumlah anakan produktif (Tabel 1).

Tinggi tanaman genotipe gandum introduksi nyata lebih rendah dari varietas Dewata sebagai pembanding, kecuali genotipe G-21 dan G-18 yang tidak berbeda nyata (Tabel 2). Keragaan tinggi tanaman seluruh genotipe berkisar antara 43.13-70.31 $\mathrm{cm}$ (Tabel 3). Keragaan tinggi tanaman tersebut jauh lebih rendah dibanding tinggi tanaman gandum di daerah subtropis, yang menurut Stroke et al. (1971) berkisar antara 90-120 cm. Budiarti (2005) mengelompokkan tanaman gandum ke dalam kategori pendek untuk tanaman dengan kisaran tinggi 53.5-65.2 $\mathrm{cm}$, sedang $(65.2-76.9 \mathrm{~cm})$, dan tinggi $(>76.9 \mathrm{~cm})$. Hasil percobaan menunjukkan bahwa seluruh genotipe gandum introduksi termasuk dalam kelompok pendek, sedangkan varietas Dewata termasuk dalam kelompok sedang $(67.94 \mathrm{~cm})$.
Subagyo (2001) mengungkapkan bahwa di daerah tropis, ketinggian tempat tanam memberi pengaruh positif terhadap tinggi tanaman dan panjang malai. Semakin tinggi tempat tanam, semakin meningkat pula tinggi tanaman dan panjang malai yang terbentuk.

Hasil analisis ragam bahwa genotipe tidak berpengaruh terhadap jumlah anakan memperlihatkan bahwa jumlah anakan yang dihasilkan genotipe gandum introduksi sama dengan jumlah anakan yang dihasilkan oleh varietas Selayar dan Dewata. Jumlah anakan yang dihasilkan semua genotipe berkisar 0.12.2 (Tabel 1).

Genotipe HP 1744 nyata berbunga lebih cepat (43 HST) dari umur berbunga varietas Selayar (47 HST) yang digunakan sebagai pembanding (Tabel 2). Umur berbunga semua genotipe selama pertanaman berkisar antara 43-70 HST (Tabel 1). Hasil ini sesuai dengan penelitian yang dilakukan di beberapa daerah di Indonesia. Penelitian tersebut menggambarkan bahwa tanaman gandum di dataran rendah (tropis)

Tabel 1. Kisaran, F-hitung, dan koefisien keragaman (KK) karakter kuantitatif beberapa genotipe gandum di dataran rendah

\begin{tabular}{|c|c|c|c|}
\hline Peubah & Kisaran & Fhitung & KK $(\%)$ \\
\hline Tinggi tanaman $(\mathrm{cm})$ & $\begin{array}{l}43.13- \\
70.31\end{array}$ & $17.74 * *$ & 5.04 \\
\hline Jumlah anakan & $0.1-2.2$ & $1.98 \mathrm{tn}$ & 39.66 \\
\hline berbunga & $43-70$ & $70.97 * *$ & 2.84 \\
\hline Jumlah anakan & $0.1-1.8$ & $1.86 \mathrm{tn}$ & 44.08 \\
\hline \multicolumn{4}{|l|}{ Produktif } \\
\hline Umur panen (HST) & $72-95$ & $9.06^{* *}$ & 4.25 \\
\hline Panjang malai $(\mathrm{cm})$ & $5.23-8.16$ & $15.83 * *$ & 4.72 \\
\hline Jumlah malai ubinan & $105-330$ & $9.91 * *$ & 11.85 \\
\hline Jumlah spikelet per & $11.5-19.2$ & $21.80 * *$ & 4.45 \\
\hline \multicolumn{4}{|l|}{ Malai } \\
\hline $\begin{array}{l}\text { Jumlah floret hampa } \\
\text { per malai }\end{array}$ & $22.5-50.7$ & $12.80 * *$ & 9.72 \\
\hline Jumlah biji per malai & $2.2-23.6$ & $11.82 * *$ & 23.06 \\
\hline $\begin{array}{l}\text { Bobot biji per malai } \\
\text { (gram) }\end{array}$ & $0.03-0.4$ & $10.26 * *$ & 23.26 \\
\hline $\begin{array}{l}\text { Bobot biji } 1000 \text { butir } \\
\text { (gram) }\end{array}$ & $\begin{array}{l}15.67- \\
25.92\end{array}$ & $6.85^{* *}$ & 9.12 \\
\hline $\begin{array}{l}\text { Hasil panen per petak } \\
\text { (gram) }\end{array}$ & $\begin{array}{l}34.8- \\
454.76\end{array}$ & $16.29 * *$ & 20.94 \\
\hline
\end{tabular}

Keterangan: $* *=$ berbeda nyata pada taraf $1 \%, *=$ berbeda nyata pada taraf $5 \%,{ }^{\text {tn }}=$ tidak berbeda nyata 
dapat berbunga lebih cepat (35-51 hari) dibandingkan dengan tanaman gandum dataran tinggi (55-60 hari) (Aqil, 2011).

Genotipe yang tidak berpengaruh nyata terhadap jumlah anakan produktif menunjukkan bahwa jumlah anakan produktif genotipe gandum introduksi yang terbentuk sama dengan jumlah anakan produktif yang dihasilkan oleh varietas Selayar dan Dewata. Jumlah anakan produktif yang dihasilkan semua genotipe selama pertanaman berkisar antara 0.1-1.8 (Tabel 1). Rendahnya jumlah anakan produktif ini dipengaruhi oleh jumlah anakan yang terbentuk. Semakin rendah jumlah anakan yang dihasilkan, maka semakin rendah pula jumlah anakan produktif yang dihasilkan oleh tanaman gandum.

Genotipe HP 1744 yang berbunga lebih cepat dari varietas Selayar sebagai pembanding, memiliki umur panen yang tidak berbeda, yaitu 75.6 HST untuk HP1744 dan 73.6 untuk Selayar. Umur panen genotipe LAJ/MO88, RABE/MO88, H-21， G-21， G-18, Menemen, dan Basribey nyata lebih lama dari umur panen varietas Selayar. Umur panen semua genotipe yang diuji berkisar antara 72-95 HST (Tabel 1). Kisaran umur panen tersebut secara umum lebih cepat dibandingkan umur panen genotipe yang ditanam di dataran tinggi.

Daradjat dan Purnawati (1994) menyatakan bahwa umur panen tanaman gandum diklasifikasikan menjadi genjah (75-85 hari), sedang (86-96 hari), dalam (97-107 hari), dan sangat dalam (>108 hari).
Hasil percobaan di lapangan menunjukkan bahwa terdapat genotipe gandum introduksi yang berumur genjah yaitu OASIS/SKAUZ//4*BCN Var-28, HP 1744, RABE/MO88, H-21, Menemen, Basribey, dan Alibey, serta berumur sedang yaitu LAJ/MO88, G21, dan G-18. Rawson et al. (1996) mengungkapkan bahwa suhu udara yang terlalu tinggi mengakibatkan meningkatnya aktivitas respirasi dan pemasakan bulir yang terlalu cepat. Hal ini berdampak pada turunnya kualitas dan kuantitas gandum yang diperoleh. Subagyo (2001) mengemukakan bahwa kisaran umur panen gandum pada elevasi $1300 \mathrm{~m}$ dpl (Kecamatan Selo) adalah sebesar 111-128 HST. Suhu yang tinggi mempengaruhi cepatnya umur panen pada beberapa varietas di daerah elevasi rendah.

\section{Karakter Komponen Hasil dan Hasil}

Genotipe sangat nyata mempengaruhi seluruh karakter komponen hasil dan hasil gandum di dataran rendah (Tabel 1). Panjang malai genotipe HP 1744 $(5.86 \mathrm{~cm}), \mathrm{LAJ} / \mathrm{MO} 88(5.97 \mathrm{~cm})$, dan RABE/MO88 $(5.79 \mathrm{~cm})$ nyata lebih pendek dari varietas Dewata $(5.79 \mathrm{~cm})$ yang digunakan sebagai kontrol, sedangkan genotipe introduksi lainnya menghasilkan malai (6.83$8.16 \mathrm{~cm}$ ) yang tidak berbeda panjangnya dari Dewata (Tabel 2).

Subagyo (2001) mengemukakan bahwa kisaran panjang malai yang terbentuk pada elevasi $1300 \mathrm{~m} \mathrm{dpl}$ (dataran tinggi) di Kecamatan Selo adalah sebesar 8.9-

Tabel 2. Nilai tengah karakter vegetatif dan generatif genotipe gandum di Bogor ( $\pm 300 \mathrm{~m} \mathrm{dpl})$

\begin{tabular}{|c|c|c|c|c|c|}
\hline Genotipe & $\begin{array}{l}\text { Tinggi tanaman } \\
(\mathrm{cm})\end{array}$ & Jumlah anakan & $\begin{array}{c}\text { Umur berbunga } \\
(\mathrm{HST})\end{array}$ & $\begin{array}{c}\text { Jumlah anakan } \\
\text { produktif }\end{array}$ & $\begin{array}{l}\text { Umur panen } \\
\text { (HST) }\end{array}$ \\
\hline $\begin{array}{l}\text { OASIS/SKAUZ// } \\
4 * \text { BCN Var- } 28\end{array}$ & 54.08-* & 0.90 & $60.00+*$ & 0.63 & 81.00 \\
\hline HP 1744 & 47.09-* & 1.10 & $43.00-*$ & 1.03 & 75.66 \\
\hline LAJ/MO88 & $46.90-*$ & 0.76 & $66.66+*$ & 0.46 & $87.66^{+*}$ \\
\hline RABE/MO88 & $48.36-*$ & 1.70 & 47.00 & 1.13 & $85.66+*$ \\
\hline $\mathrm{H}-21$ & $57.83-*$ & 0.63 & $60.00+*$ & 0.60 & $83.33+*$ \\
\hline G-21 & 61.98 & 1.56 & $65.00+*$ & 1.23 & $93.66+^{*}$ \\
\hline G-18 & 64.03 & 1.53 & $62.66+*$ & 1.26 & $90.33+*$ \\
\hline Menemen & $52.14-*$ & 0.96 & $60.00+*$ & 0.76 & $82.33+*$ \\
\hline Basribey & $52.31-*$ & 0.83 & $60.00+*$ & 0.53 & $83.33+*$ \\
\hline Alibey & $53.53-*$ & 0.96 & $55.00+*$ & 0.90 & 78.00 \\
\hline Selayar & 53.15 & 1.63 & 47.00@ & 1.43 & $73.66 @$ \\
\hline Dewata & 67.94@ & 1.16 & 50.00 & 1.10 & 76.33 \\
\hline
\end{tabular}

Keterangan : Nilai tengah tiap genotipe yang diikuti oleh tanda $\left(-^{*}\right)$ atau $\left(+^{*}\right)$ berturut-turut menunjukkan nyata lebih rendah atau lebih tinggi dari pembanding pada $\alpha=5 \%$ berdasarkan uji t-Dunnett. @): varietas pembanding untuk tiap karakter 
$10.9 \mathrm{~cm}$. Hal ini menunjukkan bahwa kisaran panjang malai pada elevasi $\pm 300 \mathrm{~m}$ dpl lebih pendek.

Jumlah malai ubinan seluruh genotipe gandum introduksi nyata lebih sedikit dari jumlah malai ubinan varietas Selayar sebagai pembanding, sedangkan genotipe Menemen dan Alibey tidak berbeda nyata (Tabel 3). Jumlah malai ubinan yang dihasilkan selama percobaan berkisar antara 105-330 malai (Tabel 1). Hampir seluruh genotipe gandum introduksi menghasilkan spikelet per malai nyata lebih sedikit dari varietas Dewata sebagai pembanding, kecuali genotipe G-21 dan G-18 yang tidak berbeda nyata (Tabel 3) Jumlah spikelet per malai yang dihasilkan selama percobaan berkisar antara 11.5-19.2 (Tabel 1).

Umumnya pada malai gandum satu spikelet mempunyai tiga floret dan masing-masing floret berisi satu biji gandum. Oleh karena itu semakin banyak jumlah spikeletnya, maka semakin banyak pula floret yang terbentuk. Hasil percobaan menunjukkan bahwa jumlah floret hampa per malai genotipe G-21 nyata lebih tinggi dari jumlah floret hampa per malai varietas Selayar yang digunakan sebagai varietas pembanding (Tabel 3). Jumlah floret hampa per malai seluruh genotipe selama percobaan berkisar antara 22.5-50.7 (Tabel 1). Tingginya jumlah floret hampa per malai memperlihatkan bahwa jumlah bji per malai yang dihasilkan semakin rendah.

Jumlah biji per malai genotipe Menemen dan
Alibey nyata lebih banyak dari jumlah biji per malai varietas Selayar yang digunakan sebagai varietas pembanding (Tabel 3). Jumlah biji per malai yang rendah disebabkan oleh faktor tingginya suhu lahan lingkungan percobaan. Van Ginkel dan Villareal (1996) mengungkapkan bahwa suhu udara yang terlalu tinggi atau rendah dapat menyebabkan terjadinya sterilitas.

Bobot biji per malai genotipe HP 1744, LAJ/ MO88, dan RABE/MO88 nyata lebih renah dari bobot biji per malai varietas Selayar yang digunakan sebagai varietas pembanding (Tabel 3). Subagyo (2001) mengemukakan bahwa kisaran bobot biji per malai yang dihasilkan di Kecamatan Selo pada elevasi 1300 $\mathrm{m}$ dpl adalah 1.31-2.66. Hal ini menunjukkan bahwa bobot biji per malai yang dihasilkan pada percobaan lebih rendah. Bobot biji 1000 butir genotipe OASIS/ SKA-UZ//4*BCN Var-28, LAJ/MO88, RABE/MO88, Menemen, dan Alibey nyata lebih sedikit dari bobot biji 1000 butir varietas Dewata sebagai varietas pembanding (Tabel 3).

Hasil panen per petak genotipe Menemen (1180.93 g) nyata lebih banyak dari hasil panen per petak varietas Selayar $(810.47 \mathrm{~g})$ sebagai pembanding (Tabel 3). Kisaran hasil panen per petak seluruh genotipe adalah 34.8-454.76 g (Tabel 1). Dugaan hasil panen rataan per hektar semua gentipe dari percobaan ini adalah 0.28 ton/ha. Hasil tersebut jauh di bawah hasil panen penelitian Bahar dan Bahri (1996) terhadap 24

Tabel 3. Nilai tengah karakter komponen hasil dan hasil genotipe gandum di Bogor $( \pm 300 \mathrm{~m} \mathrm{dpl})$

\begin{tabular}{|c|c|c|c|c|c|c|c|c|}
\hline Genotipe & $\mathrm{PM}(\mathrm{cm})$ & JMU & JSPM & JFHPM & JBPM & BBPM (g) & $\mathrm{B} 1000(\mathrm{~g})$ & HPPP (g) \\
\hline $\begin{array}{l}\text { OASIS/SKAUZ// } \\
4 * \text { BCN Var-28 }\end{array}$ & 7.18 & $196.66-*$ & $14.93-*$ & 26.86 & 17.93 & 0.29 & $17.64-*$ & 206.22 \\
\hline HP 1744 & $5.86-*$ & 197.33-* & $12.40-*$ & 31.63 & 5.56 & 0.09-* & 20.59 & $71.45-*$ \\
\hline LAJ/MO88 & $5.97-*$ & $162.00-*$ & $12.90-*$ & 32.46 & 6.23 & $0.09-*$ & 17.96-* & $65.90-*$ \\
\hline RABE/MO88 & 5.79-* & $173.33-*$ & $12.63-*$ & 32.23 & 5.66 & $0.10-^{*}$ & $16.63-^{*}$ & 114.39-* \\
\hline $\mathrm{H}-21$ & 7.22 & $226.33-*$ & $15.16^{*}$ & 31.83 & 13.66 & 0.27 & 20.13 & 229.08 \\
\hline G-21 & 7.89 & $178.33-*$ & 17.86 & $45.76+*$ & 7.83 & 0.16 & 20.86 & 149.93-* \\
\hline G-18 & 8.09 & $186.33-*$ & 17.03 & 35.7 & 15.4 & 0.33 & 23.13 & 288.49 \\
\hline Menemen & 7.18 & 263.66 & $15.50-*$ & 25.16 & $21.33+*$ & 0.36 & $16.88-*$ & $393.64+^{*}$ \\
\hline Basribey & 6.98 & $205.66-*$ & $15.10-*$ & 29.56 & 15.73 & 0.27 & 19.27 & 215.09 \\
\hline Alibey & 6.90 & 261.66 & $14.93-*$ & 25.66 & $19.13+*$ & 0.32 & $15.03-*$ & 347.37 \\
\hline Selayar & 6.83 & 298.00@ & 13.93 & 29.73@ & 12.06@ & 0.29@ & 22.57 & 270.15@ \\
\hline Dewata & 7.59@ & 154.33 & 17.23@ & 44.1 & 7.6 & 0.17 & 23.01@, & 178.47 \\
\hline
\end{tabular}

Keterangan : $\quad$ Nilai tengah tiap genotipe yang diikuti oleh tanda (-*) atau (+*) berturut-turut menunjukkan nyata lebih rendah atau lebih tinggi dari pembanding pada $\alpha=5 \%$ berdasarkan uji t-Dunnett. @ : varietas pembanding untuk tiap karakter. PM $=$ panjang malai, JMU $=$ jumlah malai per ubinan, JSPM $=$ jumlah spikelet per malai, JFHPM = jumlah floret hampa per malai, JBPM = jumlah biji per malai, BBPM = bobot biji per malai, B1000 = bobot biji 1000 butir, dan HPPP = hasil panen per petak 
galur gandum introduksi dari CIMMYT di Rambatan, Sumatera Barat ( $500 \mathrm{~m} \mathrm{dpl}$ ) yang mempunyai kisaran hasil panen antara 0.83-2.75 ton $\mathrm{ha}^{-1}$.

\section{UCAPAN TERIMA KASIH}

Penulis menyampaikan terima kasih kepada Konsorsium Gandum Nasional di bawah Badan Litbang Pertanian - Kementerian Pertanian yang mendanai penelitian ini untuk tahun anggaran 2011.

\section{DAFTAR PUSTAKA}

Aqil, M., B.P. Marcia, H. Muslimah. 2011. Inovasi gandum adaptif dataran rendah. Majalah Sinar Tani Edisi (3390):12-13.

Azwar, R., T. Danakusuma, A.A. Daradjat. 1989. Prospek Pengembangan Terigu di Indonesia. Buku I: Risalah Simposium II, Penelitian Tanaman Pangan. Pusat Penelitian Tanaman Pangan. Bogor. Hal. 225-239.

Bahar, H., L. Bahri. 1996. Keragaman pertumbuhan, komponen hasil, dan hasil tanaman terigu. Jurnal Penelitian Pertanian 15:107-113.

Balitsereal. 2009. Kemajuan pemuliaan gandum tropis. http://www.deptan.go.id. [13 Desember 2010].

Bogasari. 2001. Proyek gandum Indonesia tahun 2000. http://www.bogasariflour.com. [13 Desember 2010].

Budiarti, S.G. 2005. Karakterisasi beberapa sifat kuantitatif plasma nutfah gandum (Triticum aestivum L.). Buletin Plasma Nutfah 11(2):4954.

Dahlan, M., Rudijanto, J. Murdianto, M. Yusuf. 2003. Usulan Pelepasan Varietas Gandum. Balai Penelitian Tanaman Serealia dan Pengembangan Pertanian. Badan Penelitian dan Pengembangan Pertanian.

Daradjat, A.A. dan E. Purnawati. 1994. Karakterisasi Plasma Nutfah Terigu. Badan Penelitian dan Pengembangan Pertanian. Departemen Pertanian.
Farid, N. 2006. Pertumbuhan dan produksi enam genotipe tanaman gandum pada dataran rendah dan tanah masam. Prosiding Seminar Nasional Bioteknologi dan Pemuliaan Tanaman. Departemen Agronomi dan Hortikultura Institut Pertanian Bogor. Hal. 389-396.

Porter, J.R. 2005. Rising temperatures are likely to reduce crop yields. Nature. 436:174.

Rawson, H.M., M. Zajac, R.N. Napkoonwang. 1996. Effect of temperature light and humidity during the phase encompassing pollen meiosis on floret fertility in wheat. p. 78-84. In H.M. Rawson, K.D. Subedi (Eds.). Sterility Wheat in Subtropical Asia: Extent Causes and Solution. ACIAR Proceeding. Sydney.

Siagian, V. 2008. Mengapa Tidak Menanam Gandum?. http://www.targetmdgs.org. $\quad[01$ Desember 2010].

Stroke, J.E., V.A. Johnson, J.W. Schimdt, P.J. Mattern. 1971. Result of The First International Winter Wheat Performance Nursery. $1^{\text {st }}$ ed. University of Nebraska Collage of Agriculture. Nebraska.

Subagyo. 2001. Uji Adaptasi atau Persiapan Pelepasan Varietas Gandum di Jawa Tengah. Seminar Nasional. Balai Pengawasan dan Sertifikasi Benih Tanaman Pangan dan Hortikultura II. Semarang.

Van Ginkel, M., R.L. Villareal. 1996. Triticum L.,p. 137143. In G. J. H. Grubben and S. Partohardjono (Eds.). Plant Resources of South-East Asia (PROSEA) No. 10. Leiden. Netherland.

Wibowo. 2009. Gandum pun Bisa Tumbuh di Indonesia. http://www.agroinonesia.co.id. [01 Desember 2010]. 